\title{
Chapter 13. The multiple roles of soil animals in the interpretation of archaeological soils and sediments in lowland tropical South America
}

Doyle MCKEY

Delphine RENARD

Rumsaïs BLATRIX

Archaeologists study sediments to gain information stratified over time. However, the distinction between soils and sediments is sometimes blurred, and archaeological sediments are often affected by pedogenic (soil-forming) processes. The hybrid discipline of pedoarchaeology attempts to separate the influences of sedimentary processes from those of pedogenic processes that were operating at a site when artefacts were deposited and those that have been acting ever since (Walkington 2010).

Among these pedogenic processes are those driven by soil animals. This review will treat only questions and methods pertinent to the historical ecology of lowland South America, ignoring others. However, we cite studies conducted elsewhere when they concern environments or cultural contexts analogous to those of lowland South America. We focus on earthworms, ants and termites, because most studies concern these groups. However, soil mesofauna (e.g. mites, collembola and others) probably are of comparable importance but have been little studied.

Effects of human activities on the ecology of soil animals can last for centuries or millenia. These organisms thus bear witness to ancient human activities and how they altered soil properties and affected soil animals. However, in the search for ancient human activities and their effects, soil animals play complex roles. Soil animals worked together with humans to shape anthropogenic soils. They are thus not just witnesses, but also accomplices. The complexity goes further. Ever since archaeological sites were abandoned by humans, animals have continued to work the soil, altering the record of human activities. In addition to being witnesses and accomplices, soil animals are also evidence-tamperers. These multiple roles, whose relative importance differs among sites, make them intriguing subjects for archaeology's detective work. Information from soil animals has to be decoded, put into context and cross-checked. Before we can evaluate the testimony of soil animals, we have to understand, in a given site, (i) how they responded when humans began using or moving soils; (ii) how their actions meshed with those of humans when anthropogenic soils were being formed; and (iii) how their actions ever since the site was abandoned have altered the archaeological record.

\section{Humans alter soils-can soil fauna bear witness to ancient land use?}

Humans alter soils in multiple ways. By altering parent material and landforms, tillage, irrigation, drainage, manuring, addition of artifacts, burning and other actions all affect soil properties. The effects range from fleeting to persistent. This continuous gradation is one of the problems in defining "anthropogenic soils". Inspection of the two major soil 
classification systems, the WRB system (IUSS Working Group WRB. 2015) and the USDA system (Galbraith 2018) shows that both are still struggling to come to grips with human-altered soils. Current interest in these soils is driven by the need to identify hazards caused by industrial-scale human alteration of soils (e.g. pollution); understanding anthropogenic soils altered by past cultures is not a priority. Whereas the best-studied of these soils (e.g. terra preta) are discussed in these classifications, others (e.g. the soils of vestiges of pre-Columbian raised fields [hereinafter termed 'RF']) are hardly treated.

Many studies investigate how various human actions on soils affect soil macrofauna over short time scales (Coleman et al. 2017), and some of these examine whether soil invertebrates can be bioindicators of different land uses (Newbold et al. 2015, and chapter 12). Soil properties can also preserve information about agricultural land use over long time scales (Walkington 2010). Some work on this theme focuses on soil macrofauna, with debate on the extent to which archaeological sediments can preserve evidence of bioturbation by meso- and macrofauna in old arable soils (Davidson 2002). Recent work has shown that earthworms and termites are both strongly affected, often in quite different ways, in two kinds of soils altered by ancient human occupation in Amazonia, Amazonian Dark Earths (ADEs) and the vestiges of pre-Columbian RF in peri-Amazonian savannah floodplains (Cunha et al. 2016). We now need syntheses of the descriptive work done in archaeological contexts and experimental studies that could identify mechanisms in responses of macrofauna to humanaltered soils and relate them to observed patterns. Little is known about how addition of biochar (black carbon, a key component of ADEs) affects soil biotic communities (McCormack et al. 2013), including earthworms (Weyers \& Spokas 2011). Biochar has widely varying effects. It can be toxic to earthworms and avoided by them (Li et al. 2011); on the other hand, it can also be a food source for microorganisms and soil fauna (Ameloot et al. 2013).

\section{How soil animals contribute to the functioning of agricultural soils}

Understanding the fauna of anthropogenic soils today requires understanding the roles that these animals played when the agricultural systems that formed these soils were in operation. Soil fauna, along with all other components of biodiversity, play crucial roles in the functioning of agricultural soils (Coleman et al. 2017), particularly when there is no input of chemical fertilizers and supplying nutrients to crops depends on managing organic matter, mobilizing the nutrients it contains by decomposition, by combustion or by some combination of the two. In decomposition-based systems, soil fauna play a particularly important role in the comminution of organic matter to ever smaller particles, multiplying the surface area upon which microbial processes can act.

Although we know much about how fauna affect the functioning of agricultural soils today and over the short term, we know little about how soil fauna interacted with humans over the long term in the agricultural 
systems that gave rise to the soils and sediments studied by historical ecologists and archaeologists in the lowland tropics. Roles of soil animals in the formation of ADEs have been particularly neglected (Cunha et al. 2016). Interactions of soil animals with charcoal, a key component in the genesis of ADEs, are little understood, but potentially crucial. For example, the long-term fertility of ADEs is conferred by the presence of oxygencontaining functional groups on the surfaces of black carbon particles, creating weak negative charges that retain cations (Glaser et al. 2001; Liang et al. 2006). The strong effect on nutrient-retention capacity depends largely on comminution of charcoal fragments into small particles (Liang et al. 2006), multiplying by thousands-fold the total surface area of black carbon. Which soil animals carry out this activity appears to be unknown.

Recent studies suggest that soil animals also play unique roles in wetland raised-field agriculture, and that the interactions between soil animals and humans when these systems were in use are important in explaining the structure and properties of their soils today. Earthworms, ants and termites that live in seasonally flooded wetlands are often capable of particularly high rates of bioturbation, building mounds that enable them to escape wet-season flooding. The regularly spaced mounds made by certain earthworms and termites in seasonal floodplains often strikingly resemble some kinds of RF (Zangerlé 2016). The potential for confusion is heightened by the fact that mounds made by humans and by invertebrates sometimes co-occur, and human and non-human soil engineers even interact, in effect building RF together (Cunha et al. 2016). For example, termite mounds-in which the work of raising soils above flood levels and of concentrating nutrients has already been done-are coopted as ready-made RF by farmers in African savannah floodplains (and continue to be inhabited by termites), and there is evidence that preColumbian RF farmers in South America sometimes did the same (McKey et al. 2017). Similarly, in Africa today, bioturbation and mound-building by soil animals contribute to recycling nutrients in and around RF during fallow periods, augmenting nutrient amendments that are applied to RF (McKey et al. 2017; Comptour et al. 2018) and there are suggestions that they performed similar functions in pre-Columbian raised-field agriculture (Cunha et al. 2016).

\section{How soil animals alter archaeological sediments over time}

As stated at the beginning of the chapter, pedogenic processes often continue to alter the archaeological record in sediments, long after human activity has ceased. "However lofty its ideals, archaeology is still a subject that is actually carried out in the realm of earthworms" (Canti 2003, p. 135) and other soil animals. By ingesting, moving and mixing soilbioturbation-soil animals can "tamper with the evidence" of past human activities in many ways. Bioturbation is particularly intense in the tropics, where soil fauna is abundant and active year-round. Earthworm ingestion can destroy small plant fossils such as carbonized seeds (Tryon 2006). By locally raising soil $\mathrm{pH}$, termites can slow bone dissolution, but also accelerate bone dissolution by increasing soil porosity (McBrearty 1990). 
However, the most frequently studied effect of bioturbation by soil animals on the archaeological record is the negative impact of soil mixing on the stratigraphic integrity of archaeological sites: mixing may destroy the usefulness of the site for investigating spatial patterning and diachronic change. While plants can also drive bioturbation (e.g. tree throws), most studies concern bioturbation by diverse burrowing animals, from crayfish to mammals, but predominantly by earthworms (Stein 1983; Canti 2003) and termites (McBrearty 1990). Although bioturbation can introduce stratigraphic noise, a signal of vertical distribution of artifact assemblages may often persist. For example, earthworms often inhabit burrows permanently; the homogenizing effect of bioturbation is much less than if they changed galleries frequently (Canti 2003; Walkington 2010).

Effects of bioturbation on the vertical distribution of archaeological artifacts depend in part on the size of artifacts. Objects small enough to be ingested or moved by soil animals (e.g. plant microfossils) are subject to homogenization, whereas larger objects (most artifacts) "sink" as soil animals bring finer particles to the surface. Morin (2006) argues that in such cases faunalturbation changes the vertical distribution of artifact assemblages in predictable ways, with objects "sinking" relatively rapidly near the surface but much more slowly near the bottom of the biomantle where soil is more compact.

Taken together, studies of the effects of bioturbation on stratigraphic integrity suggest that while vertical distributions become more complex, they often remain interpretable. However, this may not be true where bioturbation rates are extremely high, as in some earth-mound landscapes in savannah floodplains (Zangerlé et al. 2016).

These studies also show that "faunalturbation is a mixed blessing" (Morin 2006): although it can blur chronological and spatial patterning, it also helps to bury artifacts where assemblages would otherwise commingle at the site surface (van Nest 2002) or be subject to erosion. Where agents of bioturbation are capable of moving large artifacts, another positive aspect is seen: by exposing artifacts on the surface, tree throws and mammal burrows enable archaeologists to locate sites without having to dig (Killgrove 2017, and chapter 6).

Soil animals can thus have diverse effects on evidence of past human activities: they can destroy or blur such evidence, they can preserve it from destruction by other causes, or they can make the evidence easier for the investigator to find.

\section{Human-made earthworks in savannah floodplains as Theseus ships}

"The ship wherein Theseus and the youth of Athens returned ... was preserved by the Athenians down even to the time of Demetrius Phalereus, for they took away the old planks as they decayed, putting in new and stronger timber in their place ... this ship became a standing example among the philosophers, for the logical question of things that grow; one side holding that the ship remained the same, and the other contending that it was not the same." (Plutarch, Life of Theseus, 75 AD) 
In savannah floodplains of South America, effects of soil animals on evidence of past human activities may be particularly complex. Earthworms, termites and ants, and the biogenic aggregates they make, are abundant in the vestiges of pre-Columbian earthworks in coastal savannahs of French Guiana (agricultural RF: McKey et al. 2010; Renard et al. 2013) and the Llanos de Mojos in Bolivia (RF: Cunha et al. 2016; earthen fish weirs: Blatrix et al. 2018). High rates of bioturbation are required of soil animals that build mounds to escape flooding (as in the Orinoco Llanos [Zangerlé et al. 2016] and the Llanos de Mojos [Cunha et al. 2016]) or that seek refuge in vestiges of human-made mounds and add to them (as in French Guiana [McKey et al. 2010] and the Llanos de Mojos [Cunha et al. 2016]). Bioturbation in vestiges of French Guianan RF is much greater than in the surrounding area, as shown by studies using the distribution of bomb cesium (Pfahler et al. 2015) as well as quantification of biogenic aggregates (Renard et al. 2013). Bioturbation may explain why paleosols are absent from the base of all but the highest French Guianan RF (McKey et al. 2010). Nevertheless, depth profiles of phytoliths and stable carbon isotopes in these RF still showed interpretable patterns. In other South American savannah floodplains, e.g. those in the Orinoco Llanos where surales earth-mound landscapes are found, bioturbation is much more intense, homogenizing phytolith distribution both vertically and horizontally (Zangerlé et al. 2016). How rates of bioturbation by soil macrofauna in the Llanos de Mojos compare with those in these other sites is unknown. However, it seems likely that in all these floodplains, bioturbation by soil macrofauna could have significant impact on stratigraphic integrity of human-made earthworks.

However, at another level, bioturbation by soil macrofauna may be the most important force saving vestiges of human-made earthworks from destruction. These earthworks are subject to erosion. Probably rarely more than 1-1.5 m high initially (if present-day African RF provide any guide: Comptour et al. 2018), erosion has often shortened them. In some areas of the Llanos de Mojos, vestiges of RF are hardly recognizable at eye level, and then more by differences in vegetation cover than in elevation (D. McKey, unpubl. field observations). McKey et al. (2010) found evidence that soil engineers preferentially establish in human-made earthworks, because they provide islands of well-drained soil. Nests of ants and termites are found only on old RF; earthworms deposit casts on old RF when they come to these non-flooded sites to breathe. Old RF thus accumulate soil brought by engineers and stabilized by their biostructures. Where environmental conditions permit high activity of soil engineers, accumulation counters the erosion of earthworks (Figure 1).

This accumulation/erosion model of the ecological functioning of vestiges of earthworks implies continuous turnover of the soil material within them. Paradoxically, some "human-made" earthworks may contain more soil put there by earthworms and termites than by humans. What is "humanmade" is the outline of the landform, preserved by the positive feedbacks driven by the tendency of earthworms and termites, ever since earthworks 
were abandoned by humans, to establish preferentially on high ground. Earthworks in savannah floodplains may thus be an example in ecosystems of Theseus ships.

\section{References}

Ameloot, N., Graber, E.R., Verheijen, F.G., and De Neve, S., 2013. Interactions between biochar stability and soil organisms: review and research needs. European Journal of Soil Science, 64 (4), 379-390.

Blatrix, R., Roux, B., Béarez, P., Prestes-Carneiro, G., Amaya, M., Aramayo, J.L., Rodrigues, L., Lombardo, U., Iriarte, J., Souza, J.G. de, Robinson, M., Bernard, C., Pouilly, M., Durécu, M., Huchzermeyer, C.F., Kalebe, M., Ovando, A., and McKey, D., 2018. The unique functioning of a preColumbian Amazonian floodplain fishery. Scientific Reports, 8 (1), 5998.

Canti, M.G., 2003. Earthworm activity and archaeological stratigraphy: a review of products and processes. Journal of Archaeological Science, 30, 135-148.

Coleman, D.C., Callaham, M.A., \& Crossley Jr, D.A., 2017. Fundamentals of soil ecology. London: Academic Press.

Comptour, M., Caillon, S., Rodrigues, L., \& McKey, D., 2018. Wetland raised-field agriculture and its contribution to sustainability: Ethnoecology of a present-day African system and questions about preColumbian systems in the American tropics. Sustainability, 10 (9), 3120.

Cunha, L., Brown, G.G., Stanton, D.W.G., Da Silva, E., Hansel, F.A., Jorge, G., McKey, D., Vidal-Torrado, P., Macedo, R.S., Velasquez, E., James, S.W., Lavelle, P., Kille, P., and Peterthe Terra Preta de Indio Network, 2016. Soil animals and pedogenesis: the role of earthworms in anthropogenic soils. Soil Science, 181 (3/4), 110-125.

Davidson, D. A., 2002. Bioturbation in old arable soils: quantitative evidence from soil micromorphology. Journal of Archaeological Science, 29 (11), 1247-1253.

Galbraith, J.M., 2018. Human-altered and human-transported (HAHT) soils in the U.S. soil classification system. Soil Science and Plant Nutrition, 64 (2), 190-199.

Glaser, B., Haumaier, L., Guggenberger, G., and Zech, W., 2001. The 'Terra Preta' phenomenon: a model for sustainable agriculture in the humid tropics. Naturwissenschaften, 88 (1), 37-41.

IUSS Working Group WRB, 2015. World Reference Base for Soil Resources 2014, update 2015 International soil classification system for naming soils and creating legends for soil maps. World Soil Resources Reports No. 106. Rome: FAO.

Killgrove, K., 2017. Six archaeological finds made by badgers. http://mentalfloss.com/article/77119/6-archaeological-finds-madebadgers 
Li, D., Hockaday, W.C., Masiello, C.A., and Alvarez, P.J., 2011. Earthworm avoidance of biochar can be mitigated by wetting. Soil Biology and Biochemistry, 43 (8), 1732-1737.

Liang, B., Lehmann, J., Solomon, D., Kinyangi, J., Grossman, J., O’Neill, B., Skjemstad, J.O., Thies, J., Luizão, F.J., Petersen, J., and Neves, E.G., 2006. Black carbon increases cation exchange capacity in soils. Soil Science Society of America Journal, 70 (5), 1719-1730.

McBrearty, S., 1990. Consider the humble termite: Termites as agents of post-depositional disturbance at African archaeological sites. Journal of Archaeological Science, 17 (2), 111-143.

McCormack, S.A., Ostle, N., Bardgett, R.D., Hopkins, D.W., and Vanbergen, A.J., 2013. Biochar in bioenergy cropping systems: impacts on soil faunal communities and linked ecosystem processes. Global Change Biology Bioenergy, 5 (2), 81-95.

McKey, D., Rostain, S., Iriarte, J., Glaser, B., Birk, J.J., Holst, I., and Renard, D., 2010. Pre-Columbian agricultural landscapes, ecosystem engineers, and self-organized patchiness in Amazonia. Proceedings of the National Academy of Sciences, USA, 107, 7823-7828.

McKey, D., Renard, D., and Comptour, M., 2017. Will the real raised-field agriculture please rise? Indigenous knowledge and the resolution of competing visions of one way to farm wetlands. In: P. Sillitoe, ed. Indigenous Knowledge: Enhancing its Contribution to Natural Resources Management. Wallingford, UK: CABI International, 116-129.

Morin, E., 2006. Beyond stratigraphic noise: unraveling the evolution of stratified assemblages in faunal turbated sites. Geoarchaeology: An International Journal, 21 (6), 541-565.

Newbold, T., Hudson, L.N., Hill, S.L.L., Contu, S., Lysenko, I., Senior, R.A., Börger, L., Bennett, D.J., Choimes, A., Collen, B., Day, J., De Palma, A., Díaz, S., Echeverria-Londoño, S., Edgar, M.J., Feldman, A., Garon, M., Harrison, M.L.K., Alhusseini, T., Ingram, D.J., Itescu, Y., Kattge, J., Kemp, V., Kirkpatrick, L., Kleyer, M., Correia, D.L.P., Martin, C.D., Meiri, S., Novosolov, M., Pan, Y., Phillips, H.R.P., Purves, D.W., Robinson, A., Simpson, J., Tuck, S.L., Weiher, E., White, H.J., Ewers, R.M., Mace, G.M., Scharlemann, J.P.W., and Purvis, A., 2015. Global effects of land use on local terrestrial biodiversity. Nature, 520 (7545), 45-50.

Pfahler, V., Glaser, B., McKey, D., and Klemt, E., 2015. Soil redistribution in abandoned raised fields in French Guiana assessed by radionuclides. Journal of Plant Nutrition and Soil Science, 178 (3), 468476.

Plutarch, 75 AD. Life of Theseus, translated by John Dryden. http://classics.mit.edu/Plutarch/theseus.html

Renard, D., Birk, J.J., Zangerlé, A., Lavelle, P., Glaser, B., Blatrix, R., and McKey, D., 2013. Ancient human agricultural practices can promote activities of contemporary non-human soil ecosystem engineers: A case 
study in coastal savannas of French Guiana. Soil Biology and Biochemistry, 62, 46-56.

Stein, J.K., 1983. Earthworm activity: a source of potential disturbance of archaeological sediments. American Antiquity, 48 (2), 277-289.

Tryon, C.A., 2006. The destructive potential of earthworms on the archaeobotanical record. Journal of Field Archaeology, 31 (2), 199-202.

Van Nest, J., 2002. The good earthworm: how natural processes preserve upland archaic archaeological sites of Western Illinois, USA. Geoarchaeology an International Journal, 17 (1), 53-90.

Walkington, H., 2010. Soil science applications in archaeological contexts: a review of key challenges. Earth-Science Reviews, 103 (3-4), 122-134.

Weyers, S.L., and Spokas, K.A., 2011. Impact of biochar on earthworm populations: a review. Applied and Environmental Soil Science, 2011, Article ID 541592.

Zangerlé, A., Renard, D., Iriarte, J., Jimenez, L.E.S., Montoya, K.L.A., Juilleret, J., and McKey, D., 2016. The Surales, self-organized earthmound landscapes made by earthworms in a seasonal tropical wetland. PloS One, 11 (5), e0154269.

\section{Figure Legend}

Figure 1. Aerial view of vestiges of pre-Columbian raised fields (RF) in a seasonally flooded coastal savannah (Savane Grand Macoua) in French Guiana, illustrating the erosion/accumulation model. Where environmental conditions favor their activity, soil engineer animals drive positive feedbacks that accumulate material on the old RF and stabilize their soils, thereby countering erosion. Where conditions are particularly favorable, mounds on the old RF may even grow and coalesce (e.g., the large mounds in the lower left). Where conditions are unfavorable for soil engineers, erosion is greater than accumulation (e.g., large areas in the central part of the image). Photograph (c) Delphine Renard. 